\title{
地域経済シミュレーションを内蔵したマルチ プロジェクト計画システムの開発とその適用
}

\author{
春名攻 $^{1 \cdot \text { 竹林幹雄 }}{ }^{2} \cdot$ 滑川達 $^{3}$ \\ ${ }^{1}$ 正会員 工博 立命館大学教授 理工学部環境システム工学科（テ 525-8571 滋賀県草津市野路町 1-1-1） \\ 2 正会員 工博 神戸大学助手 工学部建設学科 (广 657-8501 神戸市灘区六甲台町 1-1) \\ 3 学生会員 工修 立命館大学大学院博士課程 （广 525-8571 滋賀県草津市野路町 1-1-1）
}

\begin{abstract}
本稿では地域総合開発・整備計画を効率的に実施するために，事業スケジュールの最適化と地域経済モデルシ ミュレーションとをハイブリッド化したシステムの提案を行った. 最初に最適スケジュール導出に際して, カッ トネットワークを応用した求解アルゴリズムを提案し，システムに内蔵する計量経済モデルを定義した. 次に， ケーススタディとして滋賀県米原町における総合開発計画を対象として取り上げ，地域経済への波及効果とプ ロジェクトの実施時期の関係に関しても実証的に分析した。その結果，計画の初期段階では地方債発行高が高 いほどプロジェクト実施時期の違いが人口集積速度に影響するが，時間の経過に伴い実施時期の違いによる集 積の効果に変化が見られないことが把握された.
\end{abstract}

Key Words: regional development, scheduling problem, multi-project planning, econometrics, population growth

\section{1. はじめに}

財政的な裏付けの重要性が増ししつつある今日の我 が国の状況を考えれば，地方部においても，限られた 財源のもとで，地域の活性化を実現することがきわめ て重要となる.しかし, 地域活性化のための開発事業 は様々であり，各事業の整備効果を総合的に評価する システムあるいはその評価視点はいまもって未整備で あるといえる.

従来, 開発事業による整備効果の計測に関しては, 単一の事業ないしは同質の事業に対する効果計測・効 果予測を行ってきた事例が多い。例えば，肥田野ら 1$)$ は東京都における道路・鉄道・ライトレールなどの交 通機関を複合的に利用することを考慮し, 複合交通空 間の整備による効果計測をへドニック・アプローチに よる地価観測から行おうとしたものである。ここでは 静的な状態での効果計測を議論しているため，地域の 発展過程およびその過程での効果の変化といった動的 な議論に進展することが難しいなどが問題点として挙 げられよう。一方，徳永ら ${ }^{2)}$ は産業連関表を利用する ことにより，交通施設整備の産業構造の変化への影響 について検討を加えている．徳永らが提案した手法は 産業間の連関性を構造的に把握することに重点を置い
ているため，個別のプロジェクト実施（施設整備）効 果の計測が巨視的にならざるを得ない。

複数の大規模プロジェクトの影響把握を行ったもの としては戸田ら ${ }^{3)}$ の研究がある.ここでは, 近畿圏に おける複数の大規模プロジェクトを対象として，これ らが同時複合的に実施された場合の影響を計測するた めに，ESRAP という評価計測システムを提案している. しかし経済システムを明示的に取り扱っていないため， 具体的な地域構造の変化の検討を行うことはシステム の構成上困難と考えられる.

このように従来研究では, プロジェクトの取捨選択 による開発効果計測が主たる検討課題であったことが わかる. しかし，同一のブロジェクトを実施する場合 でも, 実施時期の違いにより現出する開発効果は大き く異なると考えられる.

一方, 地域開発計画における投資時期・規模に着目し たものとしては Tang ${ }^{4)}$ の研究を挙げることができる. Tang ${ }^{4)}$ は計量経済モデルに最適制御を導入し, 最適投 資規模決定問題として検討を加えている.しかし，Tang の場合，地域経済に対する部門別開発投資に関する検 討を行っているにとどまり, 個々のブロジェクト単位 での最適制御については触れておらず，実際の適用に 関しては困難であると考えられる。 
このような流れから, 実際規模の開発計画問題を取 り扱う場合, 複数の個別プロジェクトの実施時期を最 適化し,より高い開発効果が得られる手法論の確立が 必要であると考えられる. しかし, 地域開発計画にお ける，このような複数の個別プロジェクトの害施時期 の最適化問題，いわゆる『スケジューリング問題』を 取り入れた開発効果計測手法は現在まで検討されるこ とは少なかった。

プロジェクト単位のスケジュール管理は, むしろ PERT-CPMに代表される工程管理, プロジェクト・マ ネジメント論で盛んに研究されている ${ }^{5), 6)}$. 実際の地 域計画を考えた場合, プロジェクト実施により財政力 が内生的に変化するため, プロジェクト・マネジメン 卜論で検討されているスケジューリングの導入が, 効 率的な計画立案のためには不可欠であると考えられる.

本稿では, 以上のような問題認識のもとに, 地方部 における総合発展計画・基盤整備計画に焦点を当て, プ ロジェクト・マネジメントの考え方を導入した地域開 発システムを構筑し, 実証例を通してそのシステムの 有効性を検討することとする. 特に, 動学的な効果計 測を行うことを考慮し，事業（プロジェクト）実施ス ケジュールの最適化に焦点を当てて検討を加える。な お, 以後本稿で用いる「事業実施スケジュール」の定 義は,「各事業の順序関係（これをプロジェクト・ネッ トワークという) を与件とした上で, 各事業の開始時 期を示したもの」とする.

本稿では, 事業実施効果の把握と事業実施スケジュー ルの確定を同時に検討するために，ハイブリッド型の 地域開発システムの構築を行う.ここでいうハイブリッ ド型地域開発システムとは, 以下に示す 2 種類のサブ システムによって構成される統合型のマネジメント・ システムである.すなわち，

1）大規模な土地開発計画の個々の事業が計画全体に 与える影響を計測できるシミュレーションシステム (Socio Economics Simulation System; SESS)

2) 設定された目的に応じて最適なプロジェクト実行 スケジュールを与えることのできるマルチプロジェ クトプランニングシステム (Multi Project Planning System; MPPS)

によって構成される１) は特定の事業の実施スケジュー ルが地域経済に与える影響を計測するシステムであり， 一方, その社会経済システムでの計測・評価值をもと にスケジュールを最適化するシステムが 2)である．以 後, この統合型マネジメント・システムをコア・シス テムと呼ぶこととする.
本稿では，コア・システムへの入力情報が確定的に 与えられる場合を想定し, コア・システムの設計およ びその解法に焦点を絞って検討する.

\section{2. マルチプロジェクトプランニングシステム (MPPS)}

まず，前章で示したハイブリッドシステムを構成す るサブシステムの一つである MPPS について述べるこ ととする。

\section{(1) MPPS の基本構造}

マルチプロジェクトブランニングシステム (MPPS) とは, 現出する複数の開発効果を予測し, 各プロジェ クトの最適な開始時期の組み合わせを抽出するという, 複数プロジェクト間のスケジュール調整を行うもので ある。

ここで, 本稿で検討するマルチプロジェクトプラン ニングシステム (MPPS) の目的と制約条件は以下に示 すとおりである.

\section{【主目的】}

\section{全プロジェクト終了期間の最短化.}

本稿で取り上げる地域経済システムは，後述するよ うに，ブロジェクトによる投資が地域経済を刺激し，そ の結果投資予算が拡大される構造を前提としている. 同 時に将来の投資予算の割引現在価值は, 年々減少する. このため, 早期のプロジェクト完了は投資予算の割引 現在価值の低下を抑制し, 同時に早期に地域経済が拡 大することとなる.よって本稿では公共ができるだけ 早期に全プロジェクトの完了を実行する場合について 検討を行う.

【制約条件】

1) 目標人口の達成: 計画を立案する際には, その計画 が対象とする人口フレームが存在するのが通常であ る.ここでは, 目標年度における人ロフレームを外 生的に与えることとする.

2) 分配所得の維持・向上: 開発行為を行い, 基盤整備 が進む上で，分配所得が少なくとも現状維持を達成 し，できる限り前期よりも向上する方が望ましいと 考えられる.

3）産業構成比率の維持 : 公共側で望ましいと考えられ る産業構成比率を外生的に設定することで, 地域構 造の大幅な変化を抑制する。

4) プロジェクト開始のために必要な先行プロジェクト の終了およびインフラ整備水準の達成：あるプロ 
ジェクトが開始されるためには，それに先行するプ ロジェクトが終了し，なおかつプロジェクト開始に 必要なインフラ整備水準が整っている必要がある.

5）予算制約：プロジェクト実施に際し，財政の破綻を 防ぐ必要がある．このため,ここでは各プロジェク トの実施費用はプロジェクト開始と同時に開始され， 元利償還型で毎期の開発予算 (返済準備金) から毎 期一定額を返済する制約を設けることとする.

\section{(2) 定式化}

さて, MPPS は以下のように定式化することができる.

$$
\min _{\delta_{t}^{i}} Y\left(\delta_{t}^{i}\right)=\sum_{t} \Gamma_{t}\left(\sum_{i \in I} \delta_{t}^{i}\right)
$$

Sub. to

$$
\begin{gathered}
Z_{i}=\sum_{l} \delta_{l}^{i}, \text { all } \quad i \\
z_{i}=\sum_{l^{\prime}} \delta_{l^{\prime}}^{i}, \text { all } i
\end{gathered}
$$

$$
\begin{gathered}
\text { if } \delta_{t_{1^{\prime}}-1}^{i}=0 \cap \delta_{t_{1^{\prime}}}^{i}=1 \quad \delta_{t_{2^{\prime}}}^{i}=1 \cap \delta_{t_{2^{\prime}+1}}^{i}=0 \\
\text { then } \quad z_{i}=\sum_{l^{\prime}=t_{1^{\prime}}}^{t_{2^{\prime}}} \delta_{l^{\prime}}^{i}, \quad \text { all } i \\
M\left(t^{\prime}\right) \geq \sum_{i} \delta_{t^{\prime}}^{i} t_{i}^{t^{\prime \prime}} \\
r_{i}^{t^{\prime \prime}}=\frac{\left\{(1+g)^{z_{i}}(1+b)^{t^{\prime \prime}} C_{i}\right\}}{z_{i}} \\
F_{k}(t) \leq f\left(\delta_{t}^{1}, \ldots, \delta_{t}^{i}, \ldots\right), \quad \text { all } \quad t \\
W_{j}(t) \geq W_{j}(t-1) \quad \text { all } \quad j \\
h(t) \geq \rho P(t) \quad \text { all } \quad t \\
\frac{P_{j}(t)}{\sum_{j} P_{j}(t)} \geq \theta_{j} \quad \text { all } \quad j, \quad t
\end{gathered}
$$

$$
\begin{aligned}
\text { if } \quad \delta_{t}^{i}=1 \cap \delta_{t+1}^{i}=0 \quad \text { then } \begin{array}{c}
Q_{k}(t) \geq q_{i k} \\
(k=1,2,3,4)
\end{array} \\
\text { if } \delta_{t}^{u}=1 \cap \delta_{t}^{v}=1 \quad \text { then } \quad S_{u v}=0 \cap S_{v u}=0 \\
\text { if } \quad \delta_{t^{\prime}}^{u}=1 \cap \delta_{t^{\prime}}^{v}=1 \quad \text { then } \quad S_{u v}=0 \cap S_{v u}=0
\end{aligned}
$$

ここで, $i:$ プロジェクトを示すインデックス $, I:$ 計 画されているプロジェクト集合, $t$ : 計画初年度からの 経過年数, $\delta_{t}^{i}: t$ 年次にプロジェクト $i \in I$ が実行され ている場合 1 ，その他は 0 であるクロネッカーデル夕. $\Gamma_{t}(): t$ 年次にプロジェクトが 1 つでも実行されている か，ないしは $I$ に属する全てのプロジェクトが終了し

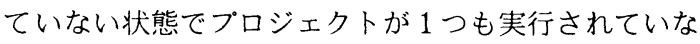
い場合に 1 ，その他は 0 を取るデル夕関数. $Y()$ :計画
期間であり，全プロジェクトの実施が完了するまでの 時間を表す。ここではプロジェクトの実施期間のみに ついて検討し，返済期間の終了まで含んだものではな い. $l$ :実施区間を示すインデックス,$l^{\prime}$ :返済区間を示す インデックス, $g$ :利子率, $b$ :物価上昇率, $C_{i}$ :現在の物 価水準で見積もったプロジェクト $i$ の総費用, $Z_{i}:$ プロ ジェクト $i$ のプロジェクト実施年数, $z_{i}$ :プロジェクト の返済年数, $t^{\prime}$ :返済年次断面, $F_{i}(t): t$ 年次における項 目 $k$ の目標とされる整備効果, $f(*):$ プロジェクトの害 施による $t$ 年次における項目 $k$ の整備効果. $M\left(t^{\prime}\right): t^{\prime}$ 年 次の返済金準備高, $r_{i}^{t \prime}: t "$ 年にプロジェクトを開始した 場合の単年度返済費用を表す。さらに, $W_{j}(t): t$ 年度に おける第 $j$ 産業就業者の分配所得, $P(t): t$ 年次におけ る人口, $P_{j}(t): t$ 年度における第 $j$ 産業従業者数, $k$ : 社 会資本整備量の種類, $Q_{k}(t): t$ 年度における社会資本 $k$ の整備量, $q_{i k}$ : プロジェクト $i$ の経営が成立するた めに必要な社会資本 $k$ の整備量, $h(t): t$ 年度における 住宅整備ストック， $\rho$ :住民一人あたりの住宅面積， $\theta_{j}$ : 目標設定された全就業人口に対する第 $j$ 産業従事者の 比率, $S_{i_{1}}, S_{i_{2}}$ : 先行可達行列 ${ }^{6)}$ の構成要素である.

変数 $h(t), P(t), P_{j}(t), M(t), W(t), Q_{k}(t)$ が次節で 述べられる地域経済モデルによって決定される值であ る.これらはスケジュールにより大きく值が変化する ため, 膨大な組み合わせ問題を解く必要が生じる．そ のため後述するアルゴリズムの導入が不可欠となる.

式 (1)は目的関数を表す.ここでは期間最短問題とし て定式化した．決定変数としてブロジェクト実施を表 す $\delta_{t}^{i}$ が該当する．式 (2) はプロジェクトの実施年数の 保存則, 式 (3) はプロジェクトにおける費用の返済年数 の保存則を表す．これら 2 式はプロジェクト開始直後 に返済開始としているものの，実施期間と返済期間が 必ずしも一致しない場合を考慮し，独立した制約条件 とした.式(4)はプロジェクト実施の連続性に関する制 約であり，プロジェクトは一度開始されれば，終了ま での期間継続的に行われるものとした.式 (5)，(6)は 返済金の合計が当該年度の予算を超過しない，という プロジェクトの実行可能性（返済保証）の制約および その返済方式の定義式を表す. 式 (7) は各年度におけ る整備効果の目標值達成の制約条件である.式 (8) は 分配所得の非逓減制約である. 式 (9) は可住面積制約, 式(10) は就業人口割合の維持に関する制約条件である。 式 (11) はプロジェクト実施に際して要求される社会資 本整備量の制約条件である。式(12)，式 (13) はそれぞ れプロジェクト実行, 返済に関する順序制約である. 


\section{（3）求解アルゴリズム}

ここではマルチブロジェクト計画問題をネットワー ク型資源配分問題として解くための解法を示す.

本稿でベ一スとする春名 ${ }^{6), 7)}$ の解法の特徵は, 工事 施エのスケジューリング問題をエ程ネットワーク上の 資源配分問題としてとらえ，そのネットワーク上に現 れる作業をルートに分解し，それを利用して作業が同 時に行うことのできる集合を表すために「カット」を 生成する方法を開発した点にある.このカットは, プロ ジェクト間の先行・後続関係を示したプロジェクトネッ トワークについて,「始点から終点までの全てのルート をただ 1 度切断する」場合に生じる作業集合である ${ }^{6)}$. 次にブロジェクトネットワークを切断した順序（レベ ル）に従ってカットを接続した「カットネットワーク」 によって改めて表現することで, PERT/MANPOWER 型問題にも対応できる解法を開発している7).

筆者らは前稿 8),99,10)において, 上記の方法論の拡 張を試みた.アルゴリズムの詳細は文献 6)〜10)に述 べてあるため, 本稿では基本手順と主な改良点を述べ るにとどめる .

\section{a) 基本手順}

基本手順 6) 10) は以下の通りである.

(メイン)

【STEP 1】レベルごとに分割された独立のカットを 生成する.

【STEP 2】 カットネットワークを生成する.

【STEP 3】 カット内の時間の決定 $\rightarrow$ サブルーチン $1 \sim$

【STEP 4】全てのカット内時間が決定されていれば 【STEP 5】へ，それ以外は【STEP 3】へ.

【STEP 5】 カットネットワークに対して動的計画法 を適用し，最短経路を探索する。

(サブルーチン 1 ) カット内時間の決定

【STEP 3-a】同一カット内にあるプロジェクト数 $Q$, $\delta_{t}^{i}$ に対応するバイナリ行列 $B_{i t}$, 費用行列 $C_{i t}$ を確定 する。

【STEP 3-b】作業期間 $u$ の期間長を $x_{u}$ とし，作業 断面行列（基底行列） $M$ を確定する。

【STEP 3-c】 $y M=\{1,1, \ldots, 1\}$ なるべクトル $y$ を 決定する.

【STEP 3-d】 プロジェクトの組み合わせべクトルを $\left\{b_{u}\right\}$ として,$\sum_{u} b_{u} y_{u}>1$ の制約下で $\sum_{u} b_{u} \leq Q$ な る最大の組み合わせ $\left\{b_{u}\right\}$ を求める.

【STEP 3-e】最小化を満足する組み合わせが存在す

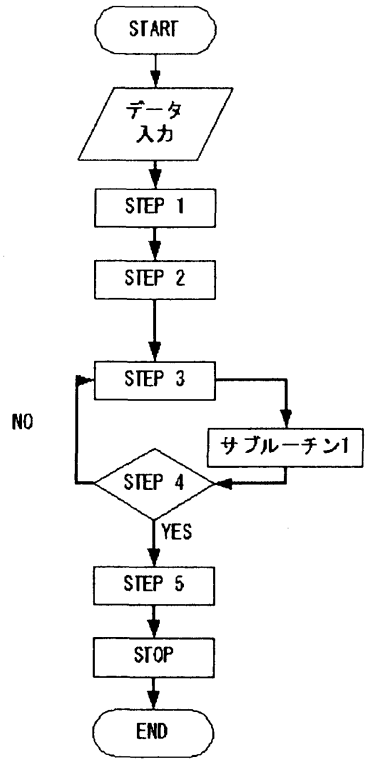

図-1 フローチャート（メイン）

れば【STEP 3-f】へ，それ以外は【STEP 3-d】へ。

【STEP 3-f】期間を短縮し， $M$ を改変する.

【STEP 3-g】 $M$ に対して, $M d=\left\{b_{1}, \ldots, b_{U}\right\}$ を満 たすべクトル $\{d\}$ を求める.

【STEP 3-h】 $\{d\}$ に対し，現在の各期の長さを示し た $x_{u}$ の同じ列の值を除した值を比較し，最小值を与え る列に着目し $\left\{b_{u}\right\}$ と入れ替え，新たな $M$ を得る.

【STEP 3-i】最小化が終了すれば【STEP 4】へ，そ れ以外は【STEP 3】へ。

\section{b) アルゴリズムの改良}

しかし，実行可能なプロジェクト費用が年毎に上昇 し，事業予算の上限が一定のような制約下では，以上 の解法のみで最適化を行っていくことは難しい，それ は改変されたブロジェクトの実施スケジュールにおい て，1事業期間内であっても年次の予算制約を満足す るとは限らない場合が存在するためである.

上記の問題は，各制約条件が作業断面では完全に把 握できないことに起因する，ゅえに，本稿ではこれら を年次断面にまで分解して検討を加える.

第 $C_{m}$ カットにおいて同時に実施できるブロジェク 卜数を $q(1 \leq q \leq Q)$ とし，そのカット内での割り当て 時間を $X_{C_{m}}^{\prime}$ とすると, 各作業断面における配分時間 $x_{u}(1 \leq u \leq Q)$ の和の最小化問題を解く際に, $q$ の最 大值 $Q$ より順に cutting stock 問題 ${ }^{11)}$ を解く.このと き, 資源制約 $q$ を満たす解のパターンを $b_{u}^{\prime}$ とする.こ の $b_{u}^{\prime}$ は短縮時間順に求めることが可能である.【STEP d-1】 
第 2 段階として，この列ベクトルの組み合わせが，予 算制約などの制約条件の満足状態を調べる.すなわち，

1) 前のカットの作業区間 $l$ からの作業 $i$ の現時点 $\bar{t}$ で の連続性の検討, すなわち,

if $\delta_{l}^{i}=1 \quad$ and $\quad \sum_{t=0}^{\bar{t}} \leq Z_{i}$

then $\delta_{l+1}^{i}=1 \quad\left(l \in V_{n}, \quad l+1 \in V_{n+1}\right)$ 【STEP d-2】

2) 各年度断面についての制約条件の検討，すなわち式 (5)の条件検討【STEP d-3】

を行い, 目的関数 (1) を最小化する組み合わせを抽出 する.これらは分肢限定法により求められる.

以上で求められたブロジェクトの実行順序で,

1) 満足する組み合わせが 1 つも存在しない場合は，先 の $b_{u}^{\prime}$ に戻って, 次の組み合わせの検討に移る.

2) 1 つでも存在する場合は, 短縮時間順に解の組み合 わせを抽出しているため，この解がカットに配分さ れる時間の最短のスケジュールを実現する実行可能 解である。

このとき, 現在検討中のカット $C_{m}$ に連続するカット を $C_{m+1}$ とする. $C_{m+1}$ が開始される最短時間は, $C_{m}$ で終了すべきブロジェクト $P_{i^{\prime}}$ の終了時期に左右され る.この $P_{i^{\prime}}$ が終了する時期を $C_{m}$ が開始後の時間と して $X_{C_{m}}$ と表すとする.この $X_{C_{m^{n}}}$ が実際にカット $C_{m}$ に配分される時間である.このとき，まだ終了しな いプロジェクト（これを $P_{i}$, とする）がある場合, 残 り時間は $P_{i}$, に必要な時間を $X T\left(P_{i^{n}}\right)$ とすると,

$\operatorname{REST} X T\left(P_{i^{\prime \prime}}\right)=X T\left(P_{i^{\prime \prime}}\right)-\left(X_{C_{m^{\prime \prime}}}-T_{\text {begin }}\left(P_{i^{\prime \prime}}\right)\right)$

となる.ただし, REST_XT $\left(P_{i "}\right)$ :作業時間の残量， $T_{\text {begin }}\left(P_{i^{\prime}}\right):$ ブロジェクト $i "$ が開始された時期である. このブロジェクトの続きは, 次のカット以降で行われ

る. (【STEP 3-j】)

また，現開始時点でどのブロジェクトも実行できない 場合は，開始時刻を 1 だけ進行させ ([STEP 3-k]), SESS により新たな制約条件を設定する。この時, 費用の増 加が予算の増加よりも早ければ将来的に実行可能性が 消失するので (【STEP 3-1】), カット内時間を無限大 とし, 後続カットの計算を終了する (【STEP 3-m】).

以上のブロセスを矛盾なく最終カットまで行う，以 上の過程を図化したものを図-2〜図-3に示す.

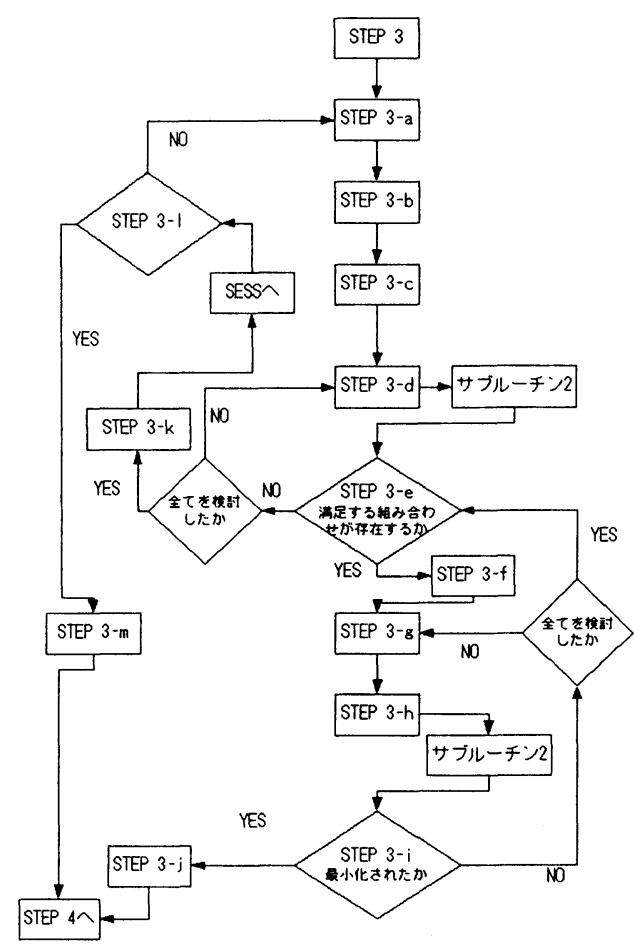

図-2 フローチャート（サブルーチン 1)

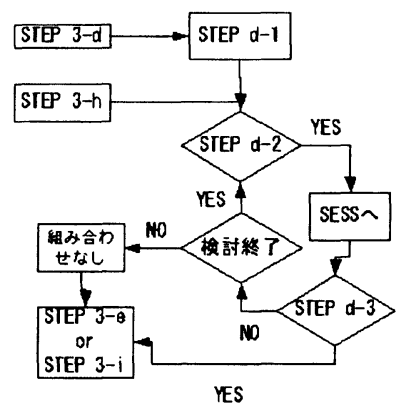

図-3 フローチャート（サブルーチン 2 )

\section{3. 地域経斉シミュレーションシステム (SESS)}

前出のマルチブロジェクトブランニングシステム (MPPS) と連動させる地域経済シミュレーションシス テム (SESS) について検討を加える.ここでは, 各プロ ジェクトの返済年数の設定や地方債の発行額, 起債夕 イミングなどに対する検討を加えるなどの総合的評価 を加えることを念頭に置き，より包括的な都市の状態 
をシミュレートすることを目指している. 本稿では個々 のシステムレベルでの記述が可能で, 地域構造を明示 的に取り扱うことに優れ，かつ恣意性の介入が比較的 少ないと考えられる計量経済に依拠した分析フレーム を地域経済シミュレーションとして用いることとした。

本稿で用いるSESS は，奥村モデル ${ }^{12)}$ に準拠したも のであるが, 経済単位が比較的小規模であること，地 域内通勤構造を表現する必要があること，および公共 による各種ブロジェクトと 3 つのセクター（人口，経 済, 財政) の関係を新たに表現しなければならないこ とから奥村モデルを以下のように調整することとした．

1）奥村モデル 12) では, ゾーン間の通勤を考慮したが， 同一ゾーン内での通勤構造は明示的に取り扱わな かった。しかし, 本稿では近隣の市町村で構成され るゾーン内での整備の経済活動に反映させる必要 があり,ゾーン内の通勤構造を明示的に取り扱い， 逆に大都市圈への遠距離通勤は取り扱わないことと した。

2) 人口の転入に関しては, 大都市圏からの流入者と周 辺地域からの流入者を区別して取り扱う。すなわち， 大都市圈からの流入者は，まず住宅整備をもとに居 住地選択を行うものとする．また，周辺地域からの 流入者はまず就業に関する条件を考慮した上で，居 住地選択を行うものとする.

3）流出についても大都市圈への流出者と周辺地域への 流出との 2 種類を取り扱うこととした.すなわち， 大都市圈への流出者は, 毎年一定割合で生じるもの と仮定し, 周辺への流出者は流入の場合と同様, 就 業項目に続いて居住地を選択するものと仮定した.

以上のような変更を加えてシステムの同定を, 実証 検討対象地域に整合する形式で行うこととする。なお， 奥村モデルの詳細に関しては参考文献 12)を参照され たい.

ここでは対象地域として米原町を含む湖北 2 市 4 町 レベル (米原町, 彦根市, 長浜市, 近江町, 山東町, 伊 吹町）で行う.このため, 『大都市圏』として取り扱わ れる都市圏としては, 近畿圏 (京阪神圏)，および中 京圏 (名古屋圈) が存在する. 本稿では簡単のため 2 つの大都市圈を単体の大都市圈として捉え直すことと し, 京阪神圈との関連によって代表させることとした。 県外（ここでは京阪神）住宅社会資本量，県外都市 計画社会資本量, および検討対象地域である湖北 2 市 4 町のうち, 実際に開発計画について検討される米原 町を除いた住宅・都市計画社会資本量, 同様に 2 市 4 町における米原町以外の所得水準・就業機会, 出生.

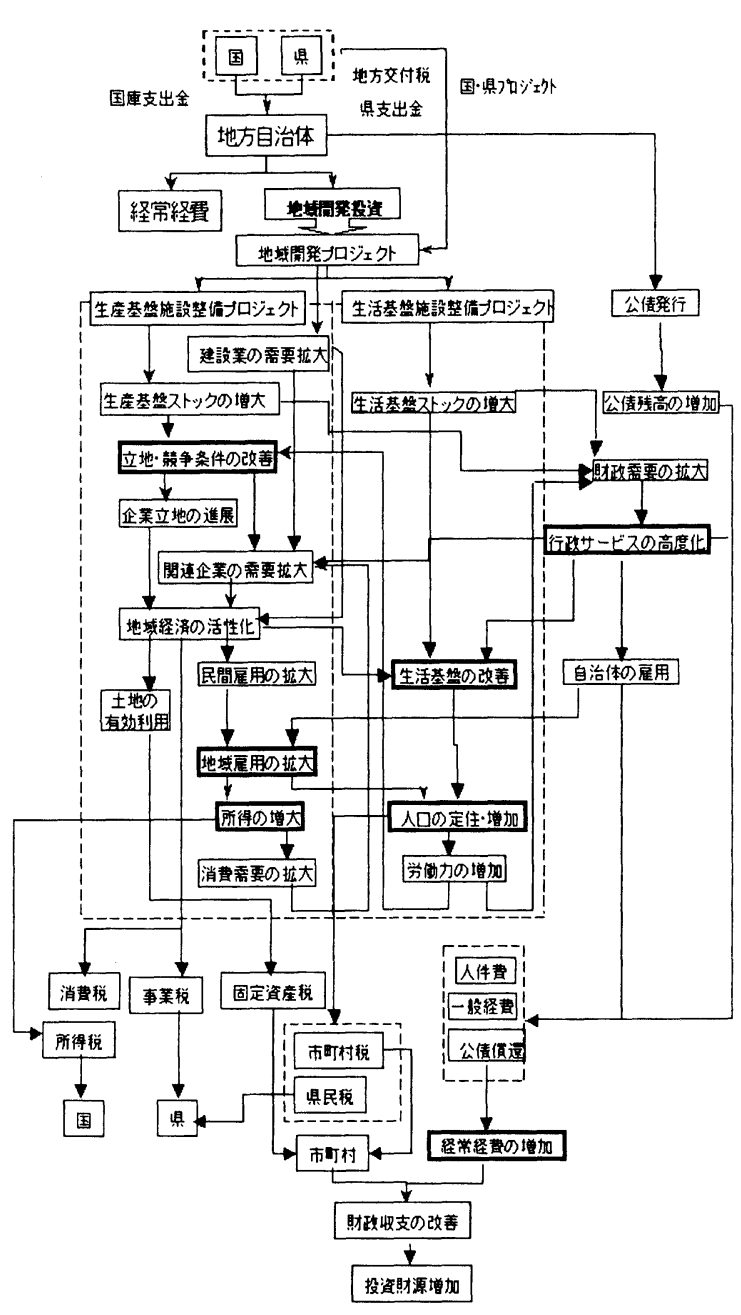

図-4 開発の波及効果

死亡率, 扶養率, 労働力化率, 退職率, 全国消費水準, 全国卸売需要率, 京阪神小売販売額, 全国労衝生産性, 全国製品需要，全国生産額，国庫・県費補助金を与件 事項とした.これ以外の数值は全てシステム内で決定 される.

また，整備による波及効果のメカニズムを図-4にま とめて示す. 図から把握されるようにプロジェクトの 投下によって各種経済活動が活性化し, 最終的には町 の財源の増加につながる構造を設定している.

パラメー夕に関しては各方程式に対して昭和 48 年か ら平成 7 年までのトレンドから推計した.そして, 再 度全体テストを行い，整合をとることとした。

本稿で採用した SESS の定式化一覧を表-1に示す. 
表-1 SESS 定式化一覧

【地域経済セクター】

\begin{tabular}{|c|c|c|c|}
\hline 項目 & 定式化 & 項目 & 定式化 \\
\hline 磦業従業人口 & $\begin{aligned} E_{1}= & E_{1}\left(Y_{1} / E 1_{-1}-Y 23 / E 23\right. \\
& \left.A l_{-1}, L-E 23_{-1}\right)\end{aligned}$ & 曹業生産額 & $O 1=O 1(E 1, A l, K g a, Z O 1 / Z E 1)$ \\
\hline 麎業分配所得 & $Y 1=Y 1(O 1)$ & 賑地面積 & $A l=A l(K g a, A H+A 2)$ \\
\hline $\begin{array}{l}\text { 製造業民間 } \\
\text { 投資額 }\end{array}$ & $\begin{array}{c}I 2=I 2\left(O 2_{-1}, Z O 2, K g r\right. \\
\left.K g i, L S / E_{-1}\right)\end{array}$ & $\begin{array}{l}\text { 製造菜民間 } \\
\text { 資本ストック }\end{array}$ & $K 2=K 2+I 2$ \\
\hline 工業用地面積 & $\begin{array}{l}A 2=A 2(K 2) \\
A 2=A 2(K 2)\end{array}$ & $\begin{array}{c}\text { 製造業従業 } \\
\text { 人口 }\end{array}$ & $\begin{array}{c}E 2=E 2\left(K 2_{-1}, E 2_{-1},\right. \\
\left.L S, E_{-1}, Z K 2 / Z E 2\right)\end{array}$ \\
\hline 製造業生产額 & $O 2=O 2\left(K 2_{-1}, Z O 2_{-1} / Z K 2_{-1}\right)$ & 製造業分配所得 & $Y 2=Y 2(O 2-Y 2)$ \\
\hline 建設業従業人口 & $E c=E c\left(O c, L S, E_{-1}\right)$ & 建設業生産額 & $O c=O c(\delta H, I 2, G n)$ \\
\hline 建設業分配所得 & $Y c=Y c(O c)$ & 総所得 & $\begin{array}{c}Y=Y 1+Y 2+Y c+Y 3 a \\
+Y 3 b+Y 3 c+Y o+Y r\end{array}$ \\
\hline 家計消費額 & $C=P c\left(Y_{-1}(\theta) / P, Z C / Z P\right)$ & 小売業販売額 & $O 3 a=O 3 a(A 3 a)$ \\
\hline 小売業分配所得 & $Y 3 a=Y 3 a(O 3 a)$ & 小売業従業人口 & $E 3 a=E 3 a(O 3 a)$ \\
\hline 発地ベースの & $O 3 b d=O 3 b d(O 3 a, O 2, Z O 3 b)$ & 卸売業販売額 & $O 3 b=\sum_{i} O 3 b d_{i} \frac{f\left(O 3 b_{-1 j}, d_{i j}\right)}{\sum_{l}^{f\left(O 3 b_{-1 l}, d_{i l}\right)}}$ \\
\hline 卸売業需要額 & & & \\
\hline 卸売業分配所得 & $Y 3 b=Y 3 b(O 3 b)$ & 卸売業従業人口 & $E 3 b=E 3 b(O 3 b)$ \\
\hline $\begin{array}{c}\text { その他 } 3 \text { 次產業 } \\
\text { 生産額 }\end{array}$ & $O 3 c=O 3 c(C, O 2, O 3 a, O 3 b, C 2)$ & $\begin{array}{l}\text { その他 } 3 \text { 次産業 } \\
\text { 分配所得 }\end{array}$ & $Y 3 c=Y 3 c(O 3 c)$ \\
\hline $\begin{array}{c}\text { その他 } 3 \text { 次産業 } \\
\text { 従業人口 }\end{array}$ & $E 3 c=E 3 c(O 3 c)$ & & \\
\hline
\end{tabular}

【地域社会・人ロセクター】

\begin{tabular}{|c|c|c|c|}
\hline 項目 & 定式化 & 項目 & 定式化 \\
\hline $\begin{array}{l}\text { 新規労微力 } \\
\text { 流出関数 }\end{array}$ & $M V=V_{-1} \frac{\exp [f(L O, Y, K g h, K g c)]}{\sum_{l} \exp \left[f\left(L O_{l}, Y, K g h_{l}, K g c_{l}\right)\right]}$ & $\begin{array}{l}\text { 転職労働力 } \\
\text { 流出関数 }\end{array}$ & $M R=L S_{-1} \frac{\exp [f(L O, Y, K g h, K g c)]}{\sum_{l} \exp \left[f\left(L O_{l}, Y, K g h_{l}, K g c_{l}\right)\right]}$ \\
\hline $\begin{array}{l}\text { 労衙力流入 } \\
\text { 関数 }\end{array}$ & $\begin{array}{l}N L=C S+R S \\
N L=C S+R S\end{array}$ & $\begin{array}{l}\text { 企業誘因労便 } \\
\text { 力流入関数 }\end{array}$ & $C S=\phi L O$ \\
\hline $\begin{array}{l}\text { 周辺地域労衝 } \\
\text { 力流入関数 }\end{array}$ & $R S=\rho R S P$ & 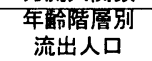 & $M_{n}=\zeta_{n} M L$ \\
\hline $\begin{array}{l}\text { 年魿階層別 } \\
\text { 流入人口 }\end{array}$ & $N_{n}=\zeta_{n}(N L+\delta C R)$ & $\begin{array}{l}\text { 母親年龄媓谱 } \\
\text { 別出生人口 }\end{array}$ & $R_{o}=1 / 5 \sum_{n} \mu_{n} P f_{-1 n}$ \\
\hline $\begin{array}{l}\text { 年蔽階層別 } \\
\text { 死亡人口 }\end{array}$ & $R_{n}=1 / 5 \xi_{n} P_{-1 n}$ & $\begin{array}{l}\text { 年路階皤別 } \\
\text { 地域人口 }\end{array}$ & $P_{n}=P_{-1 n}-R_{n}-M_{n}+N_{n}$ \\
\hline 総人口 & $P=\sum_{n} P_{n}$ & 労働カ人口 & $L=\sum_{n} \gamma_{n} P_{n}$ \\
\hline 従業人口 & $L S=L f(Y / E, C / P)$ & 新規就業人口 & $V=\sum_{n}^{n} \gamma_{n} P_{n}$ \\
\hline 就業機会 & $L O=E-E_{-1}+L_{O}$ & 退職人口 & $L_{o}=\sum_{n} \delta_{n} P_{-1 n}$ \\
\hline $\begin{array}{l}\text { 他都市への } \\
\text { 通勤人口 }\end{array}$ & $C R_{j}=E O \frac{\exp \left[f\left(K g h_{j}, K g c_{j}\right)\right]}{\sum_{l} \exp \left[f\left(K g h_{l}, K g c_{l}\right)\right]}$ & 住宅建設量 & $\Delta H=\Delta H\left(H_{-1}, P-P_{-1}\right)+\sum_{r} \delta_{r}^{h} q_{h}$ \\
\hline 住宅整備量 & $H=\eta H_{-1}+\Delta H$ & 住宅用地面積 & $A H=A H(H)$ \\
\hline
\end{tabular}

【地域財政セクター】

\begin{tabular}{|c|c|}
\hline 項目 & 定式化 \\
\hline 市町村税収 & $T 2 o=T 2 o(O 1+O 2+O c+O 3 a+O 3 b+O 3 c, Y)$ \\
\hline 市町村筬入 & $T 2=T 2 o+T 2 x+T 2 s+T 2 k+T 2 n$ \\
\hline 地方交付税 & $T 2 x=T 2 x\left(T 2_{-1}, T 2 o, C 2\right)$ \\
\hline 市町村唝残高 & $T 2 t=T 2 t\left(T 2 t_{-} 1, T 2 s\right)$ \\
\hline 市町村債賃哀貫 & $C 2 r=C 2 r\left(T 2 t_{-1}\right)$ \\
\hline 市町村経常経費 & $C 2=C 2\left(P, K_{g}, C 2 r\right)$ \\
\hline 市町村投資財源 & $S 2=T 2-C 2$ \\
\hline 社会資本ストック & $K g k=\psi K g k_{-1}+\sum_{r} \delta_{r}^{k} q_{r}$ \\
\hline
\end{tabular}

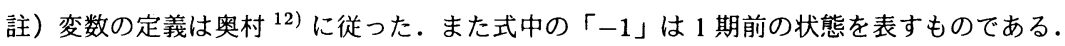


表-2 想定プロジェクト

\begin{tabular}{|c|c|c|c|c|c|}
\hline No & ブロシェらト & $\begin{array}{l}\text { 面樌 } \\
\text { (ha) }\end{array}$ & $\begin{array}{l}\text { 期间 } \\
\text { (年) }\end{array}$ & $\begin{array}{c}\text { 曹用 } \\
(10 \text { 憶田) }\end{array}$ & $\begin{array}{c}\text { 返済年数 } \\
\text { (年) }\end{array}$ \\
\hline (1) & 地嚗マネシメントセンター & 1.8 & 1 & 0.8 & $* 17$ \\
\hline (2) & 米原㧽周辺 & 1.5 & 5 & 5.5 & 0 \\
\hline (3) & マルチメティアセンター & 4.2 & 1 & *2.5 & *17 \\
\hline (4) & 駅東部土地区画整理 & 37.3 & 10 & 8.08 & *17 \\
\hline (5) & $\mathrm{JR}$ 粠研風洞実鈳所 & 2.4 & 1 & 1.5 & 0 \\
\hline (6) & 民間研究所用地 & 4.2 & 1 & 0.7 & ${ }^{* 17}$ \\
\hline (7) & 轾合病院 & 1 & 1 & 1 & 0 \\
\hline (8) & 国道 6号線 & 7 & 3 & 2.7 & 0 \\
\hline (9) & 紧道彦根米原楾 & 2.1 & 2 & 0.55 & 0 \\
\hline (10) & 米原梅が原線 & 0.7 & 1 & 0.1 & 5 \\
\hline (11) & 梅が原産根線 & 1.05 & 1 & 0.15 & 5 \\
\hline (12) & 米原北部開発 & 44.7 & 3 & 9.3 & *17 \\
\hline (13) & 米原地区 & 17 & 1 & 2.8 & *17 \\
\hline (14) & 米原周辺エリア關発 & 30 & 10 & 7.5 & $* 17$ \\
\hline (15) & 8 号線ハイイパス周辺開発 & 12.5 & 10 & 6.25 & $* 17$ \\
\hline (16) & 文教ソーン & 8.6 & 2 & 1 & $* 17$ \\
\hline (17) & アートの森開㻏 & 6 & 2 & i & $* 10$ \\
\hline (18) & 国道8易ハイパス & 9.8 & 4 & 3.8 & 0 \\
\hline (19) & 米原湖岸楾 & 0.7 & 1 & 0.1 & 5 \\
\hline (20) & 米原東西缐 & 0.7 & 1 & 0.1 & 5 \\
\hline (21) & 米原㗀線 & 0.7 & 1 & 0.1 & 5 \\
\hline (22) & 米原近江楾 & 1.4 & i & 0.2 & 8 \\
\hline (23) & 天野川線 & 1.4 & 1 & 0.2 & 8 \\
\hline (24) & 米原環状線 & 1.05 & 1 & 0.15 & 5 \\
\hline (25) & 紧道楅口岩勝線 & 2.8 & 2 & 0.7 & 0 \\
\hline (26) & 21 昜パイパス & 4.9 & 2 & 1.9 & 0 \\
\hline (27) & 梅が原西坂楾 & 2.1 & 2 & 0.3 & *15 \\
\hline (28) & 国道 21 号線 & 9.1 & 3 & 3.55 & 0 \\
\hline (29) & 紧道大津能祭川長浜線 & 4.2 & 3 & 1.1 & 0 \\
\hline (30) & 湖㚔入江地区開発 & 46.1 & 3 & $* 5.6$ & $* 17$ \\
\hline (31) & 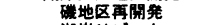 & 35.4 & 2 & 0.8 & $* 17$ \\
\hline (32) & 湖岸リソート & 27.3 & 2 & *6 & *17 \\
\hline (33) & 入江地区住宅 & 18 & 1 & 2.8 & $* 17$ \\
\hline (34) & 磎工莱団地 & 29 & 10 & 7.4 & $* 17$ \\
\hline (35) & 宫田磯工菜団地 & 14 & 1 & 1.3 & 10 \\
\hline (36) & 東西軸エリア & 4 & 5 & $* 2$ & 10 \\
\hline (37) & 㗀地区開唚 & 2 & 3 & 0.75 & 5 \\
\hline (38) & 湖岸リソートホテル & 2.6 & 2 & 14 & 0 \\
\hline (39) & 朝妻公園挞張 & 0.5 & 1 & 0.25 & 5 \\
\hline (40) & 湖岸レクソーン & 2 & 5 & 1.5 & 5 \\
\hline (41) & 大規摸公園鯂碏 & 79.8 & 3 & 1.5 & 5 \\
\hline (42) & 磯地区シシボル公圄 & 17.5 & 5 & $* 1.75$ & 10 \\
\hline (43) & 蓮原公圄执張 & 4.6 & 2 & 0.25 & $* 15$ \\
\hline (44) & 番堨地区造成 & 32 & 3 & 30 & *17 \\
\hline (45) & 番㙋地区信景 & 30.2 & 2 & 4 & $* 17$ \\
\hline (46) & 番堨彦根腺 & 3.15 & 2 & 0.45 & 10 \\
\hline (47) & 极西坂楾 & 1.4 & 1 & 0.2 & 5 \\
\hline (48) & 米原工蕉用地 & 64 & 10 & 10 & *17 \\
\hline (49) & 米原工藮団地 & 26.5 & 1 & 3.7 & *17 \\
\hline (50) & パワーセンター & 5 & 3 & 1 & 0 \\
\hline (51) & インター周辺再開発 & 60.8 & 4 & 15 & $* 17$ \\
\hline (52) & 枝折西坂楾 & 1.4 & 1 & 0.2 & 5 \\
\hline (53) & 醒井上丹生楾 & 1.75 & 1 & 0.25 & 5 \\
\hline (54) & 醒井藮落線 & 1.05 & 1 & 0.15 & 5 \\
\hline (55) & 醒并地区關無 & 3 & 3 & 0.75 & 5 \\
\hline (56) & 醒井北部開発 & 14.6 & 1 & 3.3 & $* 17$ \\
\hline (57) & 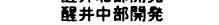 & 68.4 & 4 & 15.4 & $* 17$ \\
\hline (58) & 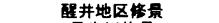 & 18.1 & 5 & $* 1.8$ & 10 \\
\hline (59) & 丹生川续最 & 2 & 5 & 0.15 & 5 \\
\hline (60) & 町厚生施設 & 1 & 1 & 1 & 0 \\
\hline (61) & 宿坦町整借 & 0.5 & 3 & 0.2 & 5 \\
\hline (62) & 譬莱関連 & 30 & 10 & *5 & 17 \\
\hline
\end{tabular}

\section{4. ケーススタディ}

\section{(1) 概要}

本稿では, システムの実用性の検証を, 滋賀県米原 町における地域開発計画を例として行うこととした.

まず, 米原町独自の機能充足のために, 米原町総合 開発計画では表-2に示される整備計画（国道 8 号, 21 号など）と町レベルで策定された整備計画（町道整備, 駅前再開発など）が提示されている.

現時点で既に駅舎整備計画など実行に移された事業 もいくつか存在するものの，大半は未だ計画のみであ る. 表中の事業費は平成 9 年当時の物価で表記した值 であり，また償還年数は他の類似事業の償還年数から 割り当てたものである.さらに*は, 後に行う分散分析 で操作対象としたプロジェクトであることを表したも

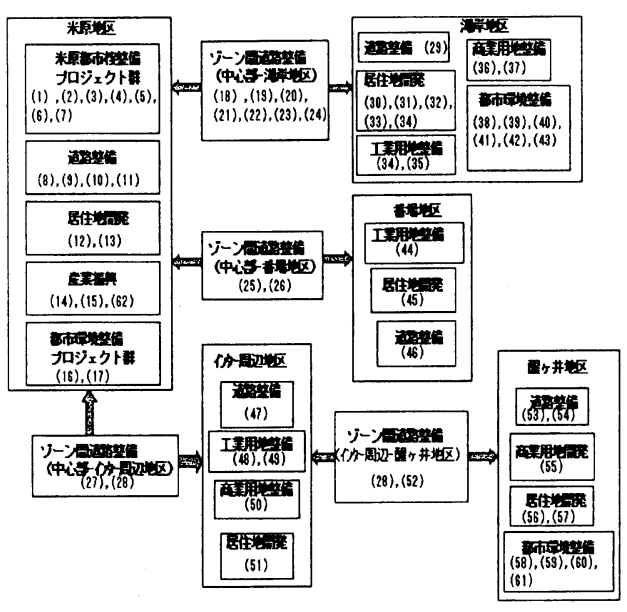

図-5＼cjkstart想定プロジェクトの関係

のであり, プロジェクト番号は後述のプロジェクトネッ トワーク (図-6参照) 中の番号と対応するものである. 米原町における都市核として米原駅周辺部が想定さ れ，交通結節点の機能，3 次産業を中心とした業務機 能の他に，フラワーバークなど町の整備方針のイメー ジ化・アメニティ向上のための機能を拡充する方針を とっている.この都市核を中心に，米原町内に合計 4 ヶ 所の拠点開発が行われる.リゾート拠点（湖岸地区）, 2 次産業拠点（番場地区），広域商業拠点（インタ一 チェンジ周辺）である.さらに，副都市核として醒井地 区を整備することとなっている。ここに述べた各拠点 の特性は，その地区の代表的な機能を表したものであ る.ゆえに，機能的には複合化されたものであり，居 住地開発など生活の基盤となる機能群は各拠点に全て 割り当てられている.

図-5は米原町総合開発計画で想定されているブロジェ クト間の関係の概略を示したものである.

分析に際しては，さらに以下の項目を加えた。

○達成人口 : 10 年後に人口 2 万人を実現することを 制約として想定した。これは現在の人口のほぼ倍に 相当する.

フプロジェクトに関する開始の制約 : 広域商業地区の 形成の中心的施設であるパワーセンターの整備に対 して, 2 市 4 町の総人口が 20 万人を越えた時点で開 始できるものと設定した.

京阪神地域からの全流出量 : 外生的に与えられ, 地 


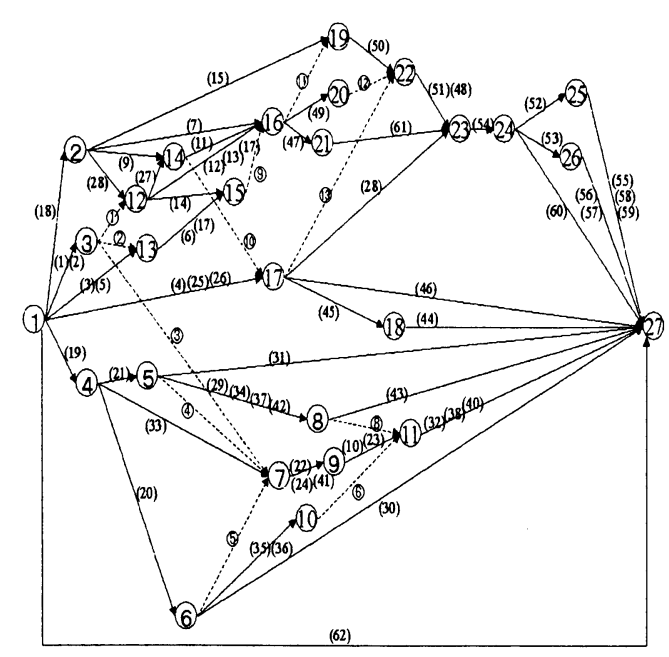

図-6 プロジェクトネットワーク

域外からの流入は京阪神地域からのものとした。

地域内の移動 : 各期ごとに行われるものとする.な お，彦根市の人口が 50 万以上である場合，彦根市へ の流入を停止するように設定した.

○各種整備ストック : 米原町以外の市町のものはトレ ンドで与えるものとする. 米原町に関しても，既存 の整備速度に変化はないものと仮定した。

○プロジェクトネットワークは, 既成市街地部から開 始し, 順次周辺部の開発を行うという想定の元で構 成されるものとする.(図-6 参照)

\section{（2）人口集積に影響を及ほすす因子評価}

まず，表-2に示した条件下での計算結果を示す．こ れを Case 1 とする. なお，本稿で採用した SESS では 人口規模が拡大するに従い, 各産業の生産力が向上し, 地域経済全体が活性化する形式となっているため，本 稿ではシステムの評価指標として人口規模を採用する こととした.

前述のアルゴリズムで計算を行った結果，カットの レベルは 27 となり,カット総数は 1046 存在する.最 適化されたプロジェクトの実施スケジュール，および その返済スケジュールを図-7, 図-8に示す.

ここでは全プロジェクト終了までに 44 年, さらに 全返済終了までに 58 年必要であることが把握された.

初期に実施されるプロジェクトは道路を中心とした もの，ついで地域マネジメントセンターやマルチメディ アセンターなど年度あたりの建設費用が比較的安価な プロジェクトを同時に実施する傾向が見られる。これ

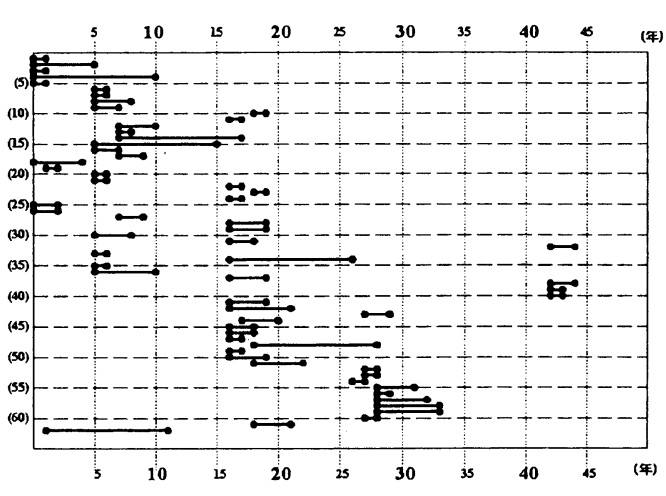

図-7 最適実施スケジュール

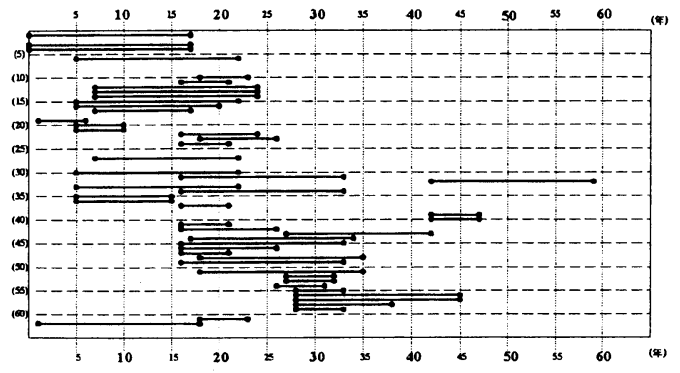

図-8 最適返済スケジュール

は道路建設を先行プロジェクトとする後続プロジェク トが全体として多いこと, 特に米原中心部の整備終了 から速やかに他の地区の整備に移行するために道路整 備が終了していなければならないという制約の影響が 大きいと考えられる.

この傾向は同時に返済スケジュールにも現れている. 国道・県道の整備は国費・県費負担となるため実質的 にブロジェクト実行の予算制約には関わらない構造と なっている.このため, 計画初期には整備可能な状態に なれば即座に着エし，返済を開始する形となっている． しかし,レベル6) が進行するに伴って, 同時検討対象 のプロジェクト数が増加し, 整備による人口集積とそ れに伴う投資財源の増加，さらには後続ブロジェクト の早期着工のために, 道路プロジェクト間にも整備の 優先順位が厳密に決定されることになる．また，人口 集積効果を高める住宅関連事業は，同時に実行される ことが望ましいという結果を得た.

さて, トレンドの変化も含めて, どのような要素が 計画期間長および人口集積速度に影響を与えるのであ ろうか.ここでは特に, 計画主体である米原町が操作 できる要素であるブロジェクト費用・返済期間（すな 
表-3 操作対象および操作方法一覧

\begin{tabular}{|c|c|c|c|}
\hline 操作因子 & 水準数 & 操作形式 & 操作対象事業 \\
\hline $\begin{array}{l}\text { 各市町村における } \\
\text { 地方債発行額 }\end{array}$ & 4 & $\begin{array}{l}1 \text { 倍, } 1.2 \text { 倍 } \\
1.5 \text { 倍, } 2 \text { 倍 }\end{array}$ & $\begin{array}{l}2 \text { 市 } 4 \text { 町地方債 } \\
\text { 発行額 }\end{array}$ \\
\hline $\begin{array}{l}\text { 各市町村における } \\
\text { 住宅関連ストック } \\
\text { 增加率 }\end{array}$ & 3 & $\begin{array}{c}1 \text { 倍, } 1.2 \text { 倍, } \\
1.5 \text { 倍 }\end{array}$ & $\begin{array}{l}2 \text { 市 } 4 \text { 町住宅 } \\
\text { 関連ストック } \\
\text { 増加率 }\end{array}$ \\
\hline $\begin{array}{l}\text { 各市町村における } \\
\text { 都市計画関連 } \\
\text { ストック增加率 }\end{array}$ & 3 & $\begin{array}{c}1 \text { 倍, } 1.2 \text { 倍, } \\
1.5 . \text { 倍 }\end{array}$ & $\begin{array}{l}2 \text { 市 } 4 \text { 町都市 } \\
\text { 計画関連 } \\
\text { ストック增加率 }\end{array}$ \\
\hline $\begin{array}{l}\text { プロジェクト } \\
\text { 費用 }\end{array}$ & 3 & $\begin{array}{c}1 \text { 倍, } 0.5 \text { 倍, } \\
0.7 \text { 倍 }\end{array}$ & $\begin{array}{l}(3),(7),(32), \\
(36),(42),(58), \\
(62)\end{array}$ \\
\hline $\begin{array}{l}\text { プロジェクト費用 } \\
\text { 返済期間長 }\end{array}$ & 3 & $\begin{array}{c}1 \text { 倍,2 倍, } \\
3 \text { 倍 }\end{array}$ & $\begin{array}{l}(1),(3),(4),(6) \\
(12),(13),(14), \\
(15),(16),(17) \\
(27),(30),(31) \\
(32),(33),(34) \\
(43),(44),(45) \\
(48),(49),(51) \\
(56),(57)\end{array}$ \\
\hline
\end{tabular}

注)「操作対象事業」列中の番号はプロジェクト番号を示す．

わち返済規模）と米原町が直接操作できない要素であ る地方債発行額・周辺市町の住宅関連ストックおよび 都市計画関連ストックの増加率を取り上げることとし た。特に, 周辺市町における整備の進行速度の違いは, 米原町を含めた 2 市 4 町の協調的な開発の可能性を模 索する上で重要である.

このため, 表-2に示される要素について, 実験計画 法により 108 ケースに関して分散分析を行うこととし た. 操作因子および操作水準は表-3に示すとおりであ り，これらを直行配列表を用いて各ケースについて割 り当てることとした. なお, 直行配列表は紙面の都合 上割愛する.

まず，ケーススタディこととに得られた人口集積の経 年変化を図-9に示すこととする. 全体的な傾向を論じ るために, いくつかのケースについての出力結果を示 すこととする. ただし，今回の場合， 20 年目で人口 2 万人を達成できない場合もいくつか存在した. その場 合 2 万人に最も近い值を実現するように条件を緩和し て計算を行った。

図より, 計画開始後 10 年目までに想定ケースごとの 人口変動が大きいことがわかる.一方 10 年目以降は, 操作項目別の変動は徐々に縮小していく傾向が認めら れ，標準状態の Case 1 の結果に近づく傾向にある。こ れは, 計画の初期段階において地域内の人口流動性に 大きく影響する因子が含まれていることを示唆するも のである.このため人口集積に関わる因子を計画初期 段階から人口流動がほぼ落ち着く開始後 20 年目まで経 年的に検討することとする.

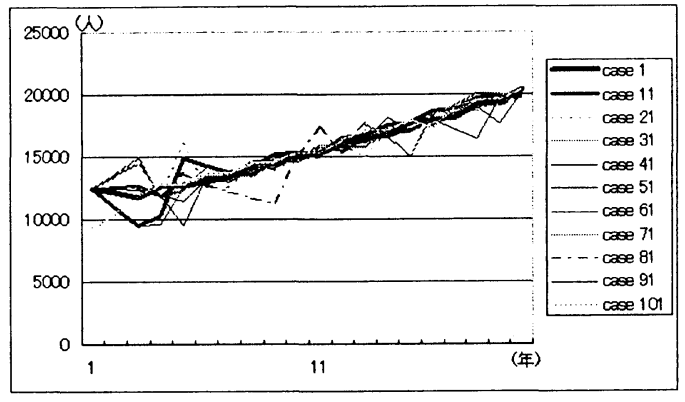

図-9＼cjkstart分散分析による人口集積の比較

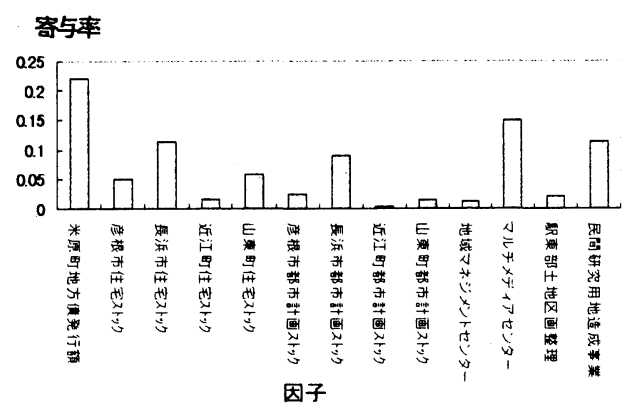

図-10 開始後 5 年目での人口增加に対する奇与率

図-10 は変動傾向が特に著しい計画開始後 5 年目に おける人口集積との関連性について寄与率 0.01 以上を 有意であるとみなし, 該当する因子を抽出したもので ある.ここでは, 米原町における地方債の発行額が上 昇することにより，人口集積が早くなり，その結果計 画期間の短縮につながることがわかる.これは, 各種 ストックの集積速度につれて人口集積の速度が上昇し, 集積数も大きくなったためであると考えられる.この 結果, 地方債の発行額が大きいほど, 集積の効果が期 待できるということになる. また，マルチメディアセン タ一の寄与率が高いのは, プロジェクトは通信インフ ラであり, 整備の規模が大きくなるにつれ, また返済 額が縮小するに伴い実施時期が早くなるにつれて，3 次産業の活性化に影響が大きいためであると考えられ る.この傾向は民間研究所用地という 3 次産業関連の 項目への寄与率が高いことからも伺える.

さらに，周辺市町の影響を見た場合，彦根の影響は 人口集積の変動には大きく関わらず，長浜や山東の住 宅関連ストックの影響が大きいという結果を得た。こ 


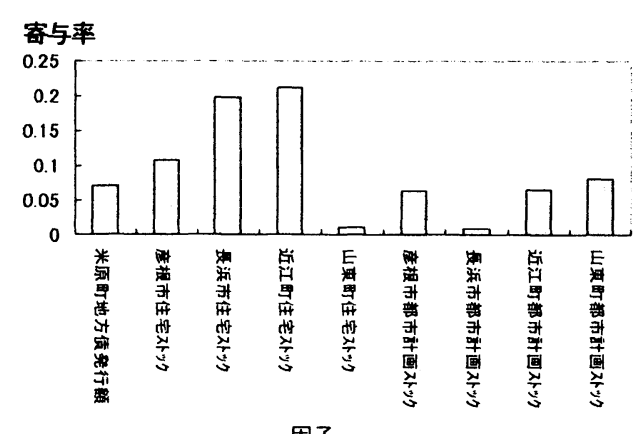

因子

図-11 開始後 20 年目での人口増加に対する寄与率

れは初期の居住地選択に関して, 山東, 長浜そしてプ ロジェクトの実施される米原における居住地選択水準 が類似の值を取る場合があることを示している．この ため，敏感な挙動を示すようになっていると考えられ る.これは住宅関連ストックでは山東よりも集積程度 の低い近江の影響が格段に小さいことからも推察され る.こういった傾向は多少の変動はあるが 10 年目に至 るまではほぼ同じであることが認められた。

最後に開始後 20 年目における影響因子について検討 を加える。

ここでも，地方債発行額の影響が見られるものの， 5 年目ほどの影響は見られない，大きく異なる点はブロ ジェクトに関わる項目が全て消失してしまう点である. すなわち, 計画開始後 20 年を経た場合, ほとんどのブ ロジェクトが完了ないしは投入済みであるためである と考えられる.むしろ，周辺市町のストックに左右さ れることを表している.特に，居住地選択行動に影響 を与える住宅ストックの影響が大きいことがわかる.

このように, ブロジェクトの実行により人口集積に 与える影響が有意となるのは 10 年目までであり，それ 以降, 特に 20 年を経る頃には, プロジェクトの実施の 影響そのものよりも, むしろ周囲の整備状況の進展に よって影響を受ける傾向にあるといえる．換言すれば 年数を経るにしたがい，ブロジェクト実施による効果 は認められるものの，実施時期の違いによる影響が見 られない傾向があるといえよう。

このため, 米原における人口集積, 経済の活性化を 考えた場合, 他の市町の整備速度よりも早く, 集積を 実行すること，すなわち先行的に投資を実行すること が望ましいといえる。なおかつ，できる限り初期の起 債額は高く，かつ返済期間は長いことが望ましいとい える。
このように，本稿で提案したマネジメントシステム を用いることによって, ブロジェクトの最適実施計画， およびその効果を計測することができることがわかり， 地域の総合開発を立案する上で有効な手段となりうる ことが確認された.さらに，設計したブロジェクトネッ トワークを再編していく上での情報も同時に抽出可能 であることが把握された。

\section{5. おわりに}

本稿は, 地方部における総合発展計画・基盤整備計 画に焦点を当て, 事業実施効果の把握と事業実施スケ ジュールの確定を同時に検討するためのハイブリッド 型の地域開発システムの構筑を行った. そして, 非線形 制約をも含めた事業スケジュール計画を定式化し，最 適化アルゴリズムを開発した。さらに，滋賀県米原町 における総合開発計画を取り上げ，本システムの有効 性を検証した. 最後に, 米原町における事業効果とし て人口集積を取り上げ，事業効果に対する各種要因の 検討を行った. 主な成果は以下に示すとおりである.

1）地域開発計画策定のための地域マネジメントシステ ムを最適化システム (MPPS) と経済シミュレーショ ンシステム (SESS) のハイブリッドシステムとして 提示した.

2) マルチブロジェクト計画問題に対して, ネットワー ク上における資源配分問題として定式化できるこ とを示し，これに対する解法アルゴリズムの開発を 行った.そして，実際規模の開発計画を例にとって 数值計算を行い, アルゴリズムの有効性を検証した。

3）米原町におけるケーススタディの結果, 計画実施の 初期段階での起債額が計画全体の速度に大きく関 わり，時間の経過と共にプロジェクト実施時期の違 いによる影響は消失する傾向にあることが把握さ れた。

本稿で提案したシステムは，過去に余り取り上げら れることの少なかった総合開発計画における最適な事 業実施計画立案に際して，有効な支援情報となること が考えられる.しかし，本研究は開発途上の部分があ ることは否めなく, 課題も多いと認識している.

1) 地域経済システムでは従来型の計量経済型のモデル を採用したことにより，ドラスティックな地域経済 の変化を前提とした場合, モデルとして適切でない と考えられる.また，経済規模の小さな地域を取り 
扱うためにバラメータの推計法に改善を加える必要 がある.また，近年では経済システムそのものが高 度に複雑化しているため, 単純化した決定論的なシ ステムでは表現できないと指摘されている.

2) 本稿で取り上げた解法では，プロジェクトネット ワークが与件として与えられなければならない。し かし，実際にはプロジェクトネットワークにおける 順序関係が確定していない場合も多い。初期に与え られるプロジェクトの先行・後続関係の規定が問題 となると考えられる。

3）事業規模は先験的に決定されているが, 社会・経済 状態に応じて事業規模を弾力的に変化させる必要 が, 現在の我が国を囲む状況からは必要であると考 えられる.この事業規模の最適化手法については現 在検討中である.

4) 本研究で対象とした問題では事業の数・種類も先験 的に決定されているが，実際にはマスタープランを 考えていく上で, 最適な事業の選択という問題が存 在する。

本稿はブロジェクトの実施順序がネットワークとい う形で集約的に表現することが可能な場合，効果を発 揮する手法であるといえる，すなわち，本稿で取り上 げたように，開発のイメージがある程度明確にされた 段階で適用することが可能である.そして，事業の新 規導入・中止によるプロジェクトネットワークの変更が 生じた場合でも，それまでの整備状況を与件として新 たなブロジェクトネットワークを作成することで，本 システムを適用し，修正された最適スケジュールを求 めることも可能である. 無論, 課題 4) でも述べたとお り，純粋に事業の選択までを一貫して検討することが 望ましいが，これに関しての具体的な解法の開発は今 後の課題である.

また，経済モデルに関しては，現在都市経済学を中 心として, 複雑系からのアプローチによる研究 13),14) が進みつつあり，地域計画においてもこの流れは無視 できないと考える. 今後は, positive feedback ${ }^{15)}$ など 経済の非線形性を考慮した地域経済モデルをシステム に内蔵することなどが望まれよう。

\section{参考文献}

1) 肥田野登, 武林雅衛 : 大都市における複合交通空間整備効 果の計測, 土木計画学研究·論文集, No.8, 121-128, 1990. 2) 徳永幸之, 稲村㹈, 須田熙, 安井誠一郎 : 構造化手法による 交通施設整備と産業構造变化との関連分析, 土木学会論文
集, No.476/IV-21, 47-56, 1993.

3) 戸田常一, 天野光三, 中川大 : 大規模プロジェクトによる地 域インパクトの計測システム, 土木計画学研究・講演集, No.10, 369-376, 1987.

4) Tang, K.C.: Optimal Control of Linear Econometric System with Linear Equality Constraints on the Control Variables, International Economic Review, Vol.20, 253-258,1979.

5) Falco, M. and Macchiaroli, R.: Timing of Control Activities in Project Planning, Int'l Journal of Project Management, Vol.16, No.1, 51-58, 1998.

6) 春名攻, 滑川達 : ネットワーク工程表の構造特性分析と最 適工程計画モデル構築に関する理論研究, 建設マネジメン 卜研究論文集 14，99-112，1996.

7) 春名攻, 滑川達 : PERT/MANPOWER 問題の最適解法の開発 研究一カットネットワークにおける最適資源配分問題への 変換を用いた新しい解法一, 土木計画学研究・論文集,No.15, 41-48,1998.

8) 春名攻, 竹林幹雄: 地域開発プロジェクトにおけるスケジュー リングに関する研究, 土木情報システムシンポジウム論文 集, 79-86, 1997.

9) 春名攻, 竹林幹雄 : 地域総合開発におけるマルチプロジェ クトプランニング実施に関する数理計画的アプローチ, 地 域学研究第 28 巻第 1 号, 207-219,1999.

10) 春名攻, 竹林幹雄, 滑川達 : マルチプロジェクト計画問題 に対応したアルゴリズムの開発, 土木情報システムシン ポジウム, 121-128, 1998.

11) Chvatal,V. : 線形計画法（下），啓学出版，1986.

12) 奥村誠, 小林潔司, 吉川和広 : 財政効果を考慮した地方開 発投資の計量経済分析, 土木計画研究・論文集,No.5, 土木 学会, 171-178, 1987.

13) W. Brian Arthur: Increasing Returns and Path Dependence in the Economy, Michigan,1994.

14) Paul Krugman: How the Economy Organizes Itself in Space, The Economy as an Evolving Complex System II, 239-262, Addison Wesley, 1997.

15) Elettra Agliardi: Positive Feedback Economies, Macmillan Press LTD, 1998. 


\title{
DEVELOPMENT OF THE MULTI-PROJECT PLANNING SYSTEM WITH REGIONAL ECONOMIC SIMULATION AND ITS APPLICATION \\ Mamoru HARUNA, Mikio TAKEBAYASHI and Susumu NAMERIKAWA
}

\begin{abstract}
The present paper aims to develop a multi-project planning system consisted in the hibread system of the project schedule optimization model and the regional economic simulation model. Moreover, the algorithm for the optimization of the project schedule is developed. The system is applied to the empirical case study on Maibara City Master Plan and analyze the relation between the project schedule and the impact of the project to the regional economy. From the computation results, the relation between the optimal project schedule and the population growth can be understood.
\end{abstract}

